\title{
Assessing the effectiveness of Hyparrhenia hirta in the rehabilitation of the ecosystem of a gold mine dump
}

\author{
$G U$ Okereafor $^{1 *}, M E$ Makhatha $^{2}, L$ Mekuto $^{3}$, and $V$ Mavumengwana $^{4}$ \\ ${ }^{1,2}$ Department of Metallurgy, School of Mining, Metallurgy and Chemical Engineering, Faculty of Engineering and the Built \\ Environment, University of Johannesburg, South Africa. \\ ${ }^{3}$ Department of Chemical Engineering, School of Mining, Metallurgy and Chemical Engineering, Faculty of Engineering and the Built \\ Environment, University of Johannesburg, South Africa. \\ ${ }^{4}$ Department of Biotechnology and Food Technology, University of Johannesburg, South Africa.
}

\begin{abstract}
The mining of gold is associated with several environmental challenges such as acid mine drainage, release of toxic metals which are associated to tailing sediments and have adversely impacted human health and the ecosystem. With increasing global population that is faced with limited land resources for agricultural activities, there is need for land restoration through effective rehabilitation of contaminated soils. The introduction of Hyparrhenia hirta, an indigenous grass specie as a phytoremediation technique for in situ rehabilitation of degraded soil is not only an economically viable approach but also environmentally friendly. Hyparrhenia hirta being a tufted and wiry perennial grass that is invasive with deep root system often aid in stabilizing the ecosystem owing to their self-fertile and drought resistant potentials that support that prevalence in harsh conditions at mine dump sites. In this study, mine tailings at Gold One Mine, Ekuhurleni, South Africa were assessed for heavy metal contents at the same time analysing the uptake of such heavy metals by Hyparrhenia hirta grass specie. The total metal mean concentrations was high $(4023.67 \mathrm{mg} / \mathrm{kg})$ for Hyparrhenia hirta which absorbed more of the following mean metal concentrations: $46.10 \mathrm{mg} / \mathrm{kg}$ for $\mathrm{Cu} ; 40.08 \mathrm{mg} / \mathrm{kg}$ for $\mathrm{Zn} ; 859.12 \mathrm{mg} / \mathrm{kg}$ for Pb; $618.26 \mathrm{mg} / \mathrm{kg}$ for $\mathrm{Cr} ; 151.70 \mathrm{mg} / \mathrm{kg}$ for $\mathrm{Co}$ and $2308.41 \mathrm{mg} / \mathrm{kg}$ for Ni. The tailings were strongly acidic with a pH range of 3.86 - 4.34. These heavy metals despite the acidic environments were successfully absorbed by Hyparrhenia hirta grass specie. Along these lines Hyparrhenia hirta was discovered reasonable for revegetation of mine tailings dump as it has the capacity to hold together tailings sediments against wind and water erosion.
\end{abstract}

\section{Introduction}

Globally, mine tailings which are usually waste products from the exploration and beneficiation of ores are on the increase and poses severe environmental hazards to both aquatic and terrestrial ecosystems due to improper management of mine tailings sites [1]. Tailings are mostly stockpiled above ground in containment areas or impoundments and often contain significant amount of several essential and non-essential metals. The concentration of metals such as, $\mathrm{Cd}, \mathrm{Fe}, \mathrm{Ni}, \mathrm{Hg}, \mathrm{Cu}, \mathrm{Mn}$, $\mathrm{Pb}$ and $\mathrm{Zn}$ in mine tailings may range from as low as $1 \mathrm{~g} / \mathrm{kg}$ to greater than $50 \mathrm{~g} / \mathrm{kg}$ [2]. At low concentration, non-essential metals are toxic whereas at higher concentrations essential metals are toxic [3].

Mine tailings are characterized by shales, cobbles, pebbles and sand sized particles, which have a very low water holding capacity and are low in nutrients such as nitrogen $(\mathrm{N})$, Potash $(\mathrm{K})$ and phosphorus $(\mathrm{P})$ and organic matter required for biological growth and soil forming processes [4]. Open dumping of mining waste and tailings deposits is a common practice in South Africa just like in other developing countries. It is noteworthy that the biotoxicity of mine tailings are supported by the presence of a low $\mathrm{pH}$ and metal content which increases the bioavailability of phytotoxic metal concentration [5]. Other features of tailings dump sites include the absence of topsoil, drought, surface mobility, periodic sheet erosion, compaction and absence of soil forming fine ingredients. Thus, the sparsely distribution of vegetation cover and a stressed heterotrophic microbial community at most mine tailings disposal sites [6]. These situations create in a sense the possibilities of having metal contaminants released during rain, resulting in metal leaching and the formation of acid mine drainages that adversely impact local streams and waterways [7]. Through food chain, several of these metals get transferred and accumulated in the bodies of animals or human beings, which previous studies are shown are responsible for DNA damage and carcinogenic effects due to their mutagenic abilities [8]. Metal toxicity of mine tailings could negatively affect the number, diversity and activity of soil organisms and the inhibition of soil organic matter decomposition. Hence it is very

\footnotetext{
* Corresponding author: guokereafor@gmail.com
} 
crucial to effectively manage mine tailing wastes to curb the release of heavy metals into the environment.

Over the years, several methods such as physical removal (excavation), in situ stabilization of heavy metals and the use of plants have been adopted in cleaning up the harmful effects of heavy metals on contaminated sites. There are remarkable merits as well as demerits associated with each of the approaches whose success is largely dependent on the nature and size of the contaminated site. Indigenous native metallicolous plants due to their potentials for immobilization of heavy metals based on documented evidences from studies are used in phytostabilization of metalliferous mine wastes [9]. They are often metal tolerant plant species with a high bioconcentration factor (metal concentration ratio of plant roots to soil) and low translocation factor (metal concentration ratio of plant shoots to roots). Because of lack of competitors, these native plant species spread easily in these environments thereby increasing the heterotrophic microbial community, which may, in turn, promote plant growth and participate in metal stabilization [10]. Grasses are potential plant species for soil stabilization on account of their growth patterns and extensive rooting systems that are fibrous. Previous studies revealed that the roots of grasses slow soil erosion rates, support the formation of organic soil, conserve soil moisture and may compete with weedy species. As a perennial grass if managed properly, Hyparrhenia Hirta which is tufted, wiry and invasive grass specie, could be used productively to rehabilitate the ecosystem on a tailing dam. It occurs throughout Africa and in Pakistan, but a wider distribution is observed in southern Africa. It has upright flowering stems which are hairless with deep root systems.

Studies in Southern Spain reported Lygeum spartum L. (family Poaceae) to tolerate severe conditions of acidity $\mathrm{pH}$ of less than 5 [11]. According to various reports, Vertiveria zizanioides (Vetiver grass) is suitable for phytostabilization of mine tailings which is attributed to its tolerance to extreme soil conditions including prolonged drought, flood, a wide range of soil acidity, alkalinity, salinity, Al, Mn and heavy metals (As, Cd, Cr, $\mathrm{Ni}, \mathrm{Pb}, \mathrm{Zn}, \mathrm{Hg}$, Se and $\mathrm{Cu}$ ) toxicities in the soil [12].

In the United Kingdom, mine waste sites containing copper, lead and zinc were stabilized by grasses Agrostis tenuis Sibthorp and Fistuca rubra [13]. Studies in China revealed plant species such as Vetiveria zizanioides, Sesbania rostrata, and Leucaena leucocephala, growing on $\mathrm{Pb} / \mathrm{Zn}$ mine tailings dumps [14]. Crops such as corn, maize and soybean were reported by [15] as potential for $\mathrm{Cu}$ phytostabilization. The suitability of four Eucalyptus (E.) species (E. cladocalyx, E. melliodora, E. polybractea, and E. viridis) from the studies of [16] for the phytostabilisation of arsenical, sulphidic gold mine tailings revealed that E. cladocalyx, as an ideal candidate for the long-term phytostabilisation of As-contaminated land and mine tailings. The spread of toxic metals to crops and vegetables due to dust storms of less vegetated mine tailings as well as the contamination of streams by surrounding mine tailings dumps which poses great danger to the health of the residence of such informal settlements were reported in the studies of [17].
Considering the importance to rehabilitate mine tailings dumps through the establishment of vegetative covers that can contain toxic metals by accumulation in their root tissues, leaves and stem; the aim of this study was to assess the concentrations of heavy metals in soils and plants, and to put forward the potential of an indigenous grass Hyparrhenia Hirta as a suitable remediation strategy for the rehabilitation of mine tailings dumps at Conservation Trust, Gold One Mine Ekuhurleni.

\section{Materials and methods}

\subsection{Study area}

The gold mine dump is in Blesbokspruit in Ekurhuleni metropolitan city of South Africa which lies on the southernmost part of the African continent, and characterized with varied topography, great natural beauty, and cultural diversity. The area is home to mild summers with temperatures seldom above $30^{\circ} \mathrm{C}$. During spring and winter, northerly and north-westerly winds occur and during summer north-easterly to north-northeasterly winds occur [18]. There are several seasonal pans across the area covering an area of about 3,559 hectares with a few lakes created by mines, which are used for recreational parks. Figure 1 detailed the location of the tailings dump while the specific description indicating coordinates of the sampling site within the dump are illustrated in Table 1.

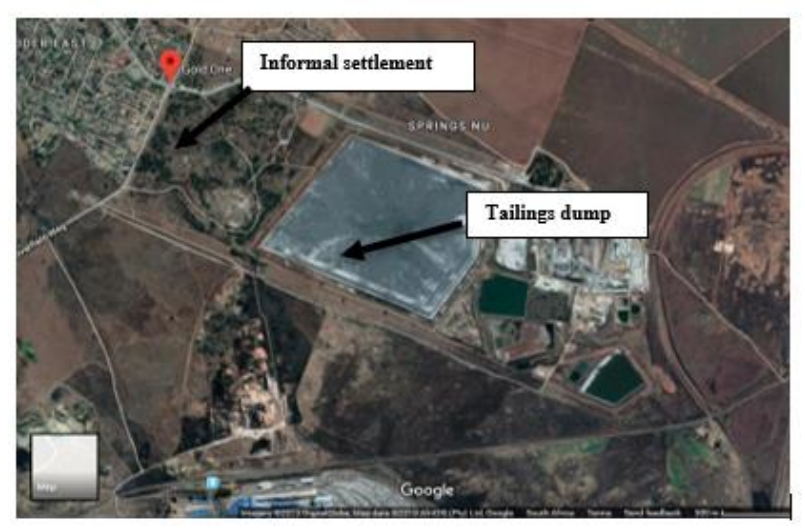

Fig. 1. Location of sampling site

\subsection{Material description}

Attempt to assess the effectiveness of identified growing grass within the tailings dump as possible rehabilitation medium for heavy metal absorption, about 2 kilograms of 20 representative tailing samples as well as 20 grass samples were obtained from an abandoned gold mine dump. Preceding the removal of top tailing samples $(2 \mathrm{~cm})$ using an auger, samples were taken at a depth of $10 \mathrm{~cm}$ for every $50 \mathrm{~m}$ horizontal interval for a wider coverage. The collected soil samples (tailings) were kept cool in an icebox $\left(<4^{\circ} \mathrm{C}\right)$ and transported to the laboratory for further analyses in sterile plastic bags. 
Table 1. GPS Co-ordinates of exact sampling location within the gold mine dump.

\begin{tabular}{ccc}
\hline Station No. & Latitude (S) & Longitude (E) \\
\hline 1 & $26010^{\prime}$ & $28027^{\prime}$ \\
2 & $26015^{\prime}$ & $28035^{\prime}$ \\
3 & $26004^{\prime}$ & $28040^{\prime}$ \\
4 & $26017^{\prime}$ & $28044^{\prime}$ \\
5 & $26021^{\prime}$ & $28050^{\prime}$ \\
6 & $26030^{\prime}$ & $29010^{\prime}$ \\
7 & $26000^{\prime}$ & $29015^{\prime}$ \\
8 & $26027^{\prime}$ & $29020^{\prime}$ \\
9 & $26009^{\prime}$ & $29035^{\prime}$ \\
10 & $26038^{\prime}$ & $29042^{\prime}$ \\
11 & $26043^{\prime}$ & $29047^{\prime}$ \\
12 & $26034^{\prime}$ & $29050^{\prime}$ \\
13 & $26013^{\prime}$ & $29053^{\prime}$ \\
14 & $26019^{\prime}$ & $30010^{\prime}$ \\
15 & $26048^{\prime}$ & $30015^{\prime}$ \\
16 & $26036^{\prime}$ & $30025^{\prime}$ \\
17 & $26040^{\prime}$ & $30029^{\prime}$ \\
18 & $26014^{\prime}$ & $30035^{\prime}$ \\
19 & $26023^{\prime}$ & $30040^{\prime}$ \\
20 & $26054^{\prime}$ & $30048^{\prime}$ \\
\hline
\end{tabular}

\subsection{Experimental analysis for heavy metal content of mine tailings and grass samples}

Using $5 \mathrm{~g}$ each, 20 representative tailing samples were oven dried at $100^{\circ} \mathrm{C}$ for 24 hours, homogenized, and grounded to pass through a $2 \mathrm{~mm}$ sieve. The determination of the $\mathrm{HCl}$-soluble fraction of heavy metals were carried out using aliquots of approximately $2 \mathrm{~g}$ of the various tailing samples weighed into a Teflon crucible and moistened with $100 \mathrm{~mL}$ of $1 \mathrm{M} \mathrm{HCl}$ acid. The mixtures were covered and placed on a shaker for 12 hours at $130 \mathrm{rpm}$. The solutions were filtered through a Whatmann filter paper, and the filtrates were stored in sterile bottles prior to heavy metal analysis using inductively coupled plasma-optical emission spectrometry (ICP-OES).

Physicochemical properties such as $\mathrm{pH}$ and EC (electrical conductivity) of the tailings were measured in a soil-to-water suspension $(1: 2.5, \mathrm{w} / \mathrm{w})$ and a 1:5 tailingsto-water suspension using a Crison multimeter (model MM 41) respectively [19]. Loss on Ignition (LOI) analysis was used to determine the organic matter content (\% OM) of the various tailing's samples [20]. The grain size distribution of tailing samples was determined using the hydrometer method [21].

For precision analysis, apparatus and glassware used were acid-washed with 5\% nitric acid while reagents were of analytical standards. Using ICP-OES (Model GBC Quantima Sequential) operated under specific conditions of $1300 \mathrm{~W}$ RF power, $15 \mathrm{~L} \mathrm{~min}^{-1}$ plasma flow, $2.0 \mathrm{~L} \mathrm{~min}^{-1}$ auxiliary flow, $0.8 \mathrm{~L} \mathrm{~min}^{-1}$ nebulizer flow and $1.5 \mathrm{~mL} \mathrm{~min}^{-1}$ sample uptake rate, detectable heavy metals were determined. The calibration of the ICP-OES equipment was done by using multiple levels of calibration standard solutions prepared from a Certipur ICP multi-element standard (Merck KGaA). Heavy metals such as $\mathrm{Cu}, \mathrm{Zn}, \mathrm{Pb}, \mathrm{Cr}$, $\mathrm{Co}$ and $\mathrm{Ni}$ determination were done using Axial view, while 2-point background correction and 3 replicates were employed in the measurement of analytical signal. The emission intensities were determined for the most sensitive lines free of spectral interference. By diluting the stock multielemental standard solution $\left(1000 \mathrm{mg} \mathrm{L}^{-1}\right)$ in $0.5 \%(\mathrm{v} / \mathrm{v})$ nitric acid, the calibration standards were prepared. The calibration curves for all the studied elements were in the range of 0.01 to $1.0 \mathrm{mg} \mathrm{L}^{-1}$. The bioaccumulation coefficient of the grass specie was carried out as described in previous studies [22].

\subsection{Data analysis}

Heavy metal concentration of $\mathrm{Cu}, \mathrm{Zn}, \mathrm{Pb}, \mathrm{Cr}, \mathrm{Co}$ and $\mathrm{Ni}$ in ppm was obtained from the recorder output of Inductively Coupled Plasma-Optical Emission Spectrometer (model - GBC Quantima Sequential) which were then expressed in $\mathrm{mg} / \mathrm{kg}$. Data with replicates were presented as mean \pm , standard deviation (SD).

\section{Results}

\subsection{Geochemical composition of gold mine tailings}

Tailings sediments from the gold mine dump exhibited an acidic $\mathrm{pH}$ within the range of 3.86 to 4.34 (Table 2). The reported acidity of the tailings could be attributed to high levels of sulphide and pyrite minerals which when exposed to oxygen and water result in acid mine drainage (AMD) [23]. From previous studies, the observed $\mathrm{pH}$ values are in line with typical $\mathrm{pH}$ value ranges of 2 to 4.4 usually found in acid mine drainage environments associated with gold and coal mining [24]. Agricultural activities may not be supported within the vicinity of the tailings dump on account of the level of acidity which may impair the uptake of major nutrients by plants. There is a likelihood based on the low CEC values for the soil not to hold enough water required by plants. The growing grass specie within the dump could be linked to the LOI which was in the range of $(5.0 \%-5.4 \%)$.

Table 2. Geochemical compositions of Gold mine dump.

\begin{tabular}{ccccc}
\hline & pH & $\begin{array}{c}\text { C.E } \\
(\mathbf{m S} / \mathbf{c m})\end{array}$ & $\begin{array}{c}\text { CEC } \\
(\mathbf{m e q} / \mathbf{1 0 0 g})\end{array}$ & $\begin{array}{c}\text { LOI } \\
(\%)\end{array}$ \\
\hline Mean & 4.12 & 1.58 & 8.84 & 5.20 \\
(SD) & 0.22 & 0.04 & 0.11 & 0.02 \\
Median & 4.28 & 1.80 & 9.10 & 5.30 \\
Min & 3.86 & 1.30 & 8.30 & 5.00 \\
Max & 4.34 & 1.90 & 9.30 & 5.40 \\
& \multicolumn{4}{l}{ Mean, (Standard deviation), $\mathrm{n}=20$} \\
\end{tabular}

\subsection{Heavy metal distribution of tailings at gold mine dump}

The levels of heavy metals such as $\mathrm{Cu}, \mathrm{Zn}, \mathrm{Pb}, \mathrm{Cr}$, Co and $\mathrm{Ni}$ were assessed at the gold mine dump (Table 3 ). 
Heavy metals widely produce toxicity both in elemental and soluble salt forms as their presence in soils often distort important chemical processes in the ecosystem. The concentration of $\mathrm{Cr}[861.50 \mathrm{mg} / \mathrm{kg}]$ was the highest followed by $\mathrm{Pb}[123.70 \mathrm{mg} / \mathrm{kg}]$, Co $[28.80 \mathrm{mg} / \mathrm{kg}]$ and $\mathrm{Ni}$ [25.40 mg/kg] respectively. The concentrations of both $\mathrm{Zn}[4.50 \mathrm{mg} / \mathrm{kg}]$ and $\mathrm{Cu}[0.20 \mathrm{mg} / \mathrm{kg}]$ were observed to be below $5 \mathrm{mg} / \mathrm{kg}$. When compared with the South African soil background values; $\mathrm{Pb}, \mathrm{Cr}$ and $\mathrm{Co}$ were seen to be $5.70,11.98$ and 1.60 times higher than the acceptable limits respectively [25]. Thus, the concentrations of these three metals in the tailings of the mine dump were significant above that of noncontaminated soils, revealing that the site was severely polluted with $\mathrm{Pb}, \mathrm{Cr}$ and $\mathrm{Co}$. soil contaminated with $\mathrm{Pb}$ disrupts the physical, chemical, and biological balance of soil systems. Previous studies reported severe health implications in inhabitants of mine areas in China as a result of pollution and soil contamination from $\mathrm{Pb}$ [26]. The accumulation of heavy metals in soils dependent on their chemical form and intensity of rainfall result in devastating environmental challenges due to alterations in biological, chemical, and physical properties of agricultural soils [27]. These heavy metals are likely to find their way into the overall ecosystem via mechanisms such as food chain, surface and groundwater contamination via erosion.

Table 3. Heavy metal concentrations of tailings from Gold mine dump $(\mathrm{mg} / \mathrm{kg})$.

\begin{tabular}{ccccccc}
\hline & $\mathbf{C u}$ & $\mathbf{Z n}$ & $\mathbf{P b}$ & $\mathbf{C r}$ & $\mathbf{C o}$ & $\mathbf{N i}$ \\
\hline Mean & 0.20 & 4.50 & 123.70 & 861.50 & 28.80 & 25.40 \\
(SD) & 0.17 & 0.57 & 1.23 & 0.79 & 0.77 & 0.91 \\
Median & 0.10 & 5.20 & 123.55 & 860.45 & 28.20 & 25.45 \\
Min & 0.10 & 3.90 & 121.90 & 860.30 & 27.30 & 23.80 \\
Max & 0.60 & 5.60 & 125.80 & 862.60 & 30.20 & 26.80 \\
Background & 29.50 & 45.20 & 21.70 & 71.90 & 18.00 & 38.70 \\
Values & \multicolumn{1}{c}{} & & \\
& Mean, (Standard deviation), $\mathrm{n}=20$ & & \\
\hline
\end{tabular}

\subsection{Heavy Metal Distribution of Plant - Hyparrhenia hirta at Gold Mine Tailings Dump}

Metal toxicity from soils heavily contaminated with metals such as $\mathrm{Mn}$. $\mathrm{Cd}, \mathrm{Cu}, \mathrm{Pb}$ and $\mathrm{Zn}$ adversely affect the quantity, diversity and activity of soil organisms; inhibits soil organic matter decomposition and reduces Nmineralization process [1]. In general, the normal heavy metal levels of terrestrial plants cultivated in uncontaminated soils are in the range of $0.4-45.8 \mathrm{mg} / \mathrm{kg}$ for $\mathrm{Cu}, 1-160 \mathrm{mg} / \mathrm{kg}$ for $\mathrm{Zn}, 0.1-41.7 \mathrm{mg} / \mathrm{kg}$ for $\mathrm{Pb}$, $0.006-18 \mathrm{mg} / \mathrm{kg}$ for $\mathrm{Cr}, 0.1-10 \mathrm{mg} / \mathrm{kg}$ for C0 and $0.4-$ $3.7 \mathrm{mg} / \mathrm{kg}$ for $\mathrm{Ni}$ [28]. The concentrations of metal in plants vary with the plant species as their uptake from soil occurs either passively with the mass flow of water into the roots, or through active transport across the plasma membrane of root epidermal cells. The bioavailability of heavy metals to plants is governed by factors such as the nature of the soil, the total concentration of heavy metal in the soil and their chemical forms [29]. Unlike other mine dumps,
Hyparrhenia hirta was the only specie of grass found growing around the site Figure 2. The concentrations of heavy metals in the leaves of plants sampled in this study are presented in Table 4 . The results indicate that the mean accumulated heavy metals were found to be 46.10 $\mathrm{mg} / \mathrm{kg}$ for $\mathrm{Cu} ; 40.08 \mathrm{mg} / \mathrm{kg}$ for $\mathrm{Zn} ; 859.12 \mathrm{mg} / \mathrm{kg}$ for $\mathrm{Pb}$; $618.26 \mathrm{mg} / \mathrm{kg}$ for $\mathrm{Cr} ; 151.70 \mathrm{mg} / \mathrm{kg}$ for Co and 2308.41 $\mathrm{mg} / \mathrm{kg}$ for Ni. Zinc is one of the most essential elements for plants but when compared with the concentrations of uncontaminated soil is low. This trend could be associated with the readiness with which it can be precipitated as the insoluble sulphate in the rhizosphere, thus preventing potential uptake and transport to the aerial parts of plants [29]. The ability of Hyparrhenia hirta to survive in such acidic conditions and absorb these heavy metals validate their usage for revegetation and stabilization of the tailings dump against wind and water erosion which supports the findings in previous studies [1].

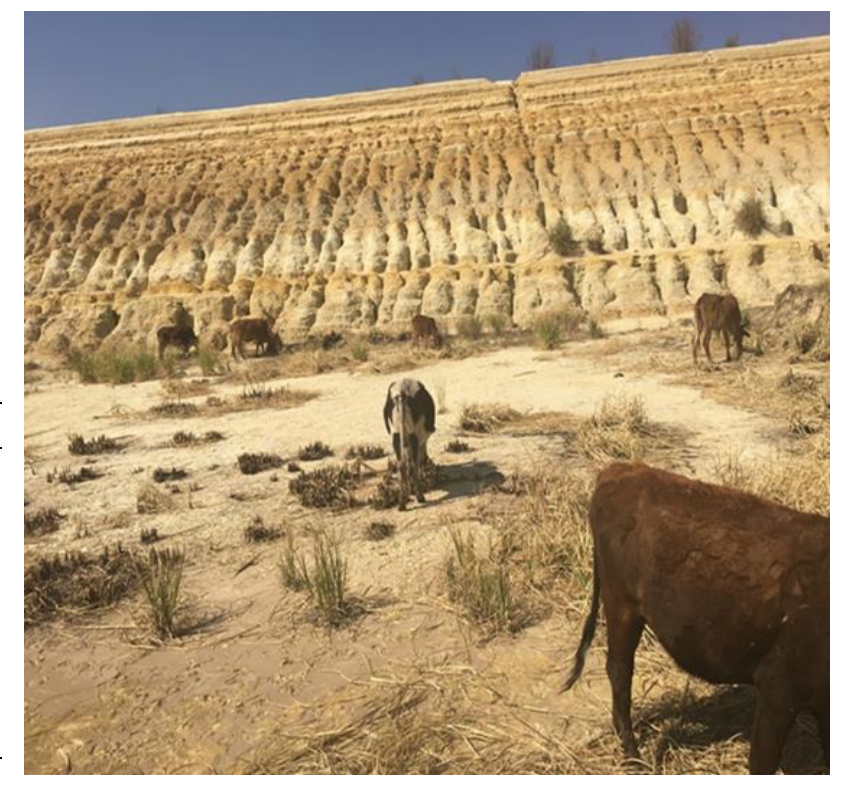

Fig. 2. Grass specie (Hyparrhenia hirta) at the gold mine dump.

Table 4. Heavy metal uptake by Grass specie (Hyparrhenia hirta) at the gold mine dump ( $\mathrm{mg} / \mathrm{kg})$.

\begin{tabular}{ccccccc}
\hline & $\mathbf{C u}$ & $\mathbf{Z n}$ & $\mathbf{P b}$ & $\mathbf{C r}$ & $\mathbf{C o}$ & $\mathbf{N i}$ \\
\hline Mean & 46.1 & 40.1 & 859.1 & 618.3 & 151.7 & 2308.4 \\
(SD) & 0.5 & 0.5 & 5.1 & 2.8 & 0.8 & 0.5 \\
Median & 46.3 & 39.9 & 861.5 & 617.8 & 151.4 & 2308.4 \\
Min & 5.13 & 39.1 & 851.5 & 614.4 & 150.3 & 2307.5 \\
Max & 5.33 & 40.9 & 867.2 & 624.5 & 152.7 & 2309.6 \\
\multicolumn{6}{c}{ Mean, (Standard deviation), $\mathrm{n}=20$} \\
\hline
\end{tabular}

\subsection{Phytoaccumulation of heavy metals and implications for phytoremediation}

Hyperaccumulators (plants) capable of striving in soils with very high concentrations of metals, absorbing such metals through their roots, and concentrating extremely high levels of metals in their tissues must exhibit a Biological accumulating coefficient (BAC) greater than 1 
[22]. It is evident that Hyparrhenia hirta qualifies to be referred to as hyperaccumulator for heavy metals $\mathrm{Cu}, \mathrm{Zn}$, $\mathrm{Pb}, \mathrm{Co}$ and $\mathrm{Ni}$. The findings from this study agree with those of [22] in the phytoaccumulation of $\mathrm{Cu}$ and $\mathrm{Ni}$ metals in tailings from mine dumps. Both metals are possible hazards humans and animals and thus should be removed from the environment.

Considering the subsistence farming within the tailings dump site and the grazing of cattle as indicated in figure 3 , there is a likelihood for heavy metals to be transferred from the tailings to the grasses, cattle and subsequently humans.

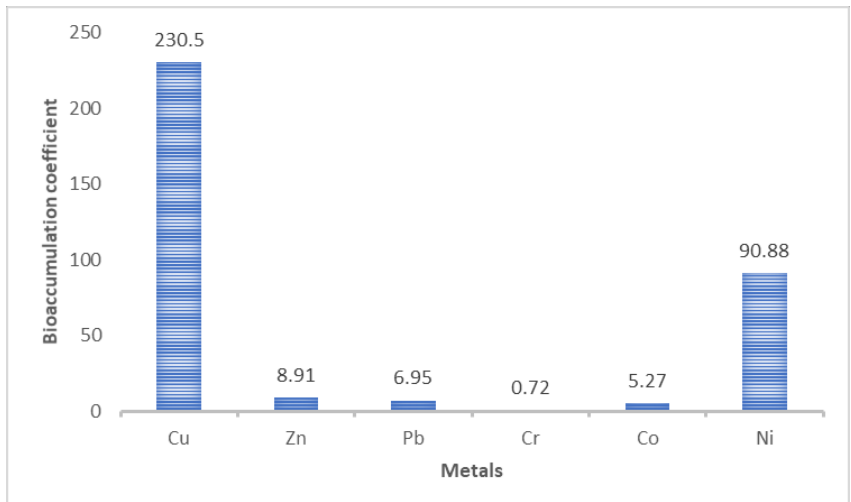

Fig. 3. The bioaccumulation coefficient (BAC $=[$ metal $]$ leave / [metal] tailings) for heavy metals of Hyparrhenia hirta at the gold mine tailings dump.

\section{Conclusion}

The study revealed that the gold mine tailings and grass Hyparrhenia hirta contained heavy metals mean concentrations, $\mathrm{mg} / \mathrm{kg},(\mathrm{Cu}[0.20 ; 46.10], \mathrm{Zn}[4.50$; 40.08], $\mathrm{Pb}[123.70 ; 859.12], \mathrm{Cr}$ [861.50; 618.26], Co [28.80; 151.70], Ni [25.40;2308.41]) with alarming $\mathrm{pH}$ ranges of $3.86-4.34$ and $5.13-5.33$ respectively that poses danger to the immediate community and the environment. Hyparrhenia hirta found within the tailings dump may be qualified as an hyperaccumulator as it is suitable for rehabilitation of the tailings dump. However, the usage of Hyparrhenia hirta for the revegetation of the site may not be efficient due to the sparsely growth pattern observed leaving the area susceptible to soil erosion after heavy rainfall or windstorm, thus transporting tailings to nearby water sources.

The authors acknowledge the services provided by the School of Mining, Metallurgy and Chemical Engineering, Faculty of Engineering and the Built Environment, University of Johannesburg, South Africa.

\section{References}

1. Rashed MN, J. Hazard. Mater. 178: 739-746 (2010).

2. Bradshaw AD, Humphreys MO, Johnson MS, 311314 (1978).

3. Frerot H, Lefebvre C, Gruber W, Collin C, Dos Santos A, Escarre J, Plant Soil. 282: 53-65 (2006).
4. Das M, Maiti SK, Asian J. Water Environ. Pollut. 4 (1) :169-176 (2006).

5. Stevenson FJ, Cole MA, John Wiley and Sons, Inc., New York (1999).

6. Mendez MO, Maier RM, Environ. Heal. Perspec. 116 (3): 278-283 (2008b).

7. USEPA (US Environmental Protection Agency) (2004).

8. Muhammad S, Shah MT, Khan S, Microchem. J. 98: 334-343 (2011).

9. Conesa HM, Schulin R, Nowack B, Water Air Soil Pollut. 183: 201-212 (2007).

10. Glick BR, Biotechnol. Adv. 21: 383-393 (2003).

11. Conesa HM, Schulin R, Nowack B, Water Air Soil Pollut. 183: 201-212 (2007).

12. Dalton PA, Smith RJ, Truong PNV, Agri. Water Manage. 31: 91-104 (1996)

13. Smith RAH, Bradshaw AD, Trans. Inst Min. Metall. Sec. A. 81: 230-237 (1979).

14. Yang B, Shu WS, Ye ZH, Lan CY, Wong MH, Chemosphere. 52: 1593-1600 (2003).

15. Zhou LB, Dai HW, Wu YJ, Gao JH, Ning YP, Wang ZY Min. Technol. 2 (2): 54-56 (2002).

16. King DJ, Doronila AI, Feenestra C, Baker AJM, Woodrow IE, Sci. Total Environ. 406 (1-2): 35-42 (2008).

17. Conesa HM, Moradi AB, Robinson BH, Kühne G, Lehmann E, Schulin R, Environmental and Experimental Botany. 65: 198-204 (2009).

18. EMM (Ekurhuleni Metropolitan Municipality) (2007).

19. Aris AZ, Ismail FA, Ng HY, Praveena SM, Pertanika J. Sci. \& Technol. 22 (2): 553 - 566 (2014).

20. Robertson S, SFU Soil Science Lab (2011).

21. ASTM D422-63 (2007).

22. Moreno-Jiménez E, Peñalosa JM, Manzano R, Carpena-Ruiz RO, Gamarra R, Esteban E, J. Hazard. Mater, 15 (162): 854-859 (2009).

23. Renu, Agarwal M, Singh K, Journal of Water Reuse and Desalination 7 (4): 387-419 (2016).

24. Reclamation Research Group (2008).

25. Herselman JE, (2007).

26. Ogbonna PC, Emea R, Teixeira da Silva JA, Toxicological \& Environmental Chemistry. 93 (5): 895 - 903 (2011).

27. Ogbonna PC, Okeke VI, Terrestrial and Aquatic Environmental Toxicology. 5: 35 - 39 (2011).

28. Prasad MNV, second edition, Norosa Publishing House, USA (2004).

29. Hao Q, Jiang C Acta Ecologica Sinica 35: 46 51(2015). 